\title{
Przebieg współpracy gospodarczej między Polską a państwami Partnerstwa Wschodniego po 1992 roku*
}

\section{The course of economic cooperation between Poland and the Eastern Partnership countries after 1992}

\section{Abstract}

The article presents the current state of conditions for the development of economic ties between Poland and the Eastern Partnership countries after 1992. Over the next few years, relations between Poland and the former USSR states gradually evolved as a result of the introduced economic reforms, the opening of economies and changes in the international environment. From the formal and legal point of view, the development of trade and the broader economic ties between Poland and the Eastern Partnership countries began in 1991, and we have had adequate, relatively comparable statistical data since 1995 . The most important changes took place when Poland joined the European Union. An important platform for intensifying cooperation with the former USSR states was created by the launch of the EU Eastern Partnership initiative, which covers Armenia, Azerbaijan, Belarus, Georgia, Moldova and Ukraine. Therefore, the study covered the state of economic ties between Poland and the Eastern Partnership countries. The study attempts to show the place of Poland in the foreign trade of the EaP countries and vice versa, outlining the trend of the dynamics of trade between the above-mentioned partners and determining the degree of complementarity of the trade structure.

* Publikacja została dofinansowana ze środków subwencji przyznanej Uniwersytetowi Ekonomicznego w Krakowie. 
Keywords: Armenia, Azerbaijan, Belarus, Georgia, Moldova, Poland, Ukraine, trade, foreign investment, economic cooperation

\section{Экономическое сотрудничество Польши со странами Восточного партнерства после 1992 года}

\section{Аннотация}

В статье представлено современное состояние условий для развития экономических связей между Польшей и странами Восточного партнерства после 1992 года. В течение следующих лет на отношения Польши со странами бывшего СССР влияли экономические преобразования, открытие экономик и изменения в международной среде. С юридической точки зрения развитие торговли и более широких экономических связей между Польшей и странами Восточного партнерства началось в 1991 году, но мы располагаем сравнительно сопоставимыми статистическим данными начиная с 1995 года Наиболее важные изменения произошли, когда Польша вошла в состав Европейского Союза. Важной платформой для активизации сотрудничества со странами бывшего СССР стал запуск инициативы ЕС «Восточное партнерство», которая охватывает Армению, Азербайджан, Беларусь, Грузию, Молдову и Украину. Таким образом, данное исследование охватывало состояние экономических связей между Польшей и странами Восточного партнерства. В исследовании делается попытка показать место Польши во внешней торговле стран Восточного партнерства и наоборот, выявить тенденцию динамики торгового обмена между вышеупомянутыми партнерами и определить степень взаимодополняемости торговой структуры.

Ключевье слова: Азербайджан, Армения, Беларусь, Грузия, Молдавия, Польша, Украина, внешняя торговля, прямые иностранные инвестиции, экономическое сотрудничество

Drzemiany historyczne związane $\mathrm{z}$ rozpadem „bloku wschodniego” spowodowały powstanie nowych państw na terenach b. ZSRR. Polska również znalazła się w zmienionych warunkach, które wymuszały kształtowanie polityki wschodniej na nowych zasadach. Szczególnie dotyczyło to ułożenia polityki gospodarczej na warunkach wolnego rynku. Zainteresowanie współpracą stopniowo rozwijało się od połowy lat 90.XX wieku. W kolejnych latach relacje między Polską a państwami b. ZSRR stopniowo ewaluowały wskutek wprowadzanych reform gospodarczych, otwierania gospodarek i zmian na arenie 
międzynarodowej. Najistotniejsze zmiany nastąpiły w wyniku wejścia Polski do Unii Europejskiej. Ważnym impulsem, prowadzącym do intensyfikacji współpracy z państwami b. ZSRR, była inicjatywa Partnerstwa Wschodniego, obejmująca: Armenię, Azerbejdżan, Białoruś, Gruzję, Mołdawię i Ukrainę.

$\mathrm{Z}$ formalno-prawnego punktu widzenia rozwój handlu i szerzej rozumianych powiązań gospodarczych między Polską a państwami Partnerstwa Wschodniego rozpoczął się w 1991 roku, zaś odpowiednimi, w miarę porównywalnymi danymi statystycznymi dysponujemy dopiero od roku 1995. W związku z tym zakres czasowy badania w przypadku handlu obejmuje lata 1995-2019, a w przypadku bezpośrednich inwestycji zagranicznych - lata 2006-2019. Celem opracowania jest przedstawienie, na tle potencjału gospodarczego, aktualnego stanu uwarunkowań rozwoju powiązań gospodarczych Polski z państwami Partnerstwa Wschodniego, które objęto dokładnym badaniem. W opracowaniu podjęto próbę pokazania miejsca Polski w handlu zagranicznym państw PW, nakreślenia trendu dynamiki wymiany handlowej między wymienionymi partnerami oraz określenia poziomu komplementarności struktury wymiany handlowej.

\section{Potencjał gospodarczy i aktualny stan uwarunkowań rozwoju powiązań gospodarczych Polski z państwami PW}

Państwa Partnerstwa Wschodniego łącznie dysponują potencjałem porównywalnym z potencjałem gospodarczym Polski, o czym świadczą dane zawarte w tabeli 1 .

Tabela 1. Udział Polski i państw PW w powierzchni, ludności i PKB świata w 2019 roku, w \%

\begin{tabular}{|l|c|c|c|}
\hline Wyszczególnienie & Powierzchnia & Ludność & PKB \\
\hline Polska & 0,24 & 0,50 & 0,68 \\
\hline Armenia & 0,02 & 0,04 & 0,02 \\
\hline Azerbejdżan & 0,07 & 0,13 & 0,05 \\
\hline Białoruś & 0,16 & 0,12 & 0,07 \\
\hline Gruzja & 0,05 & 0,05 & 0,02 \\
\hline Mołdawia & 0,03 & 0,05 & 0,01 \\
\hline Ukraina & 0,46 & 0,59 & 0,18 \\
\hline
\end{tabular}

Źródło: obliczenia własne na podstawie danych Banku Światowego. 
W 2019 roku powierzchnia państw PW stanowiła ok. 0,79\% ogólnej powierzchni świata (z Polską łącznie 1,03\%), zaś liczebność mieszkańców stanowi ok. 0,98\% ludności świata (z Polską łącznie ok. 1,48\%).W analizowanym roku na państwa PW przypadało zaledwie 0,35\% PKB świata, zaś na Polskę - 0,68\%. Było to efektem oddziaływania wielu różnorodnych czynników, w tym m.in. zróżnicowanych efektów transformacji gospodarczej, ukształtowania zróżnicowanych struktur gospodarczych i zróżnicowanego stopnia wykorzystania możliwości płynących z aktywnego uczestnictwa w międzynarodowym podziale pracy (tabela 2 ).

Tabela 2. Struktura gospodarki Polski i państw PW w 2019 roku, w \%

\begin{tabular}{|c|c|c|c|c|c|c|}
\hline & \multirow{2}{*}{$\begin{array}{c}\text { Udział sektora } \\
\text { prywatnego } \\
\text { w tworzeniu } \\
\text { PKB }\end{array}$} & \multicolumn{3}{|c|}{ Struktura tworzenia PKB } & \multicolumn{2}{|c|}{ Struktura popytu } \\
\hline & & Rolnictwo & Przemysł & Usługi & $\begin{array}{c}\text { Kon- } \\
\text { sumpcja }\end{array}$ & $\begin{array}{c}\text { Akumu- } \\
\text { lacja }\end{array}$ \\
\hline Polska & 72,3 & 2,35 & 28,65 & 57,52 & 75,54 & 19,75 \\
\hline Armenia & 29,9 & 11,99 & 24,29 & 54,23 & 95,91 & 17,45 \\
\hline Azerbejdżan & 14,9 & 5,72 & 48,69 & 37,36 & 67,54 & 20,14 \\
\hline Białoruś & 24,6 & 6,78 & 31,30 & 48,82 & 70,91 & 28,98 \\
\hline Gruzja & 21,1 & 6,51 & 20,31 & 60,77 & 83,32 & 27,22 \\
\hline Mołdawia & 31,8 & 10,05 & 22,77 & 54,08 & 98,62 & 25,95 \\
\hline Ukraina & 47,0 & 9,01 & 22,56 & 54,43 & 95,23 & 13,00 \\
\hline
\end{tabular}

Źródło: obliczenia własne na podstawie danych: World Bank, https://databank. worldbank.org/ [dostęp 1.01.2021]; Statistics on small and medium-sized enterprises in EU and the Eastern Partnership countries, The European Commission, https://ec.europa. eu/i www.eu4business.eu [dostęp 1.01.2021]; Raport o stanie sektora małych i średnich przedsiębiorstw 2020, Polska Agencja Rozwoju Przedsiębiorczości, Warszawa 2020, s. 14

Gospodarki państw, które nas interesują, różnią się wielkością udziału sektora prywatnego w gospodarce. Pomijając Polskę, ten udział jest stosunkowo najwyższy na Ukrainie, zaś najniższy w Azerbejdżanie. Armenia, Mołdawia i Ukraina wyróżniają się najwyższym udziałem rolnictwa w tworzeniu dochodu narodowego. Natomiast Polska, podobnie jak większość państw PW, cechuje się porównywalnym udziałem przemysłu w tworzeniu PKB. Tu wyjątek stanowią tylko Białoruś i Azerbejdżan, gdzie w porównaniu z Polską udział ten jest odpowiednio większy o 2,65 p.p. i 20,04 p.p. Państwa PW są zróżnicowane również pod względem udziału usług w gospodarce. 
Najwyższy poziom udziału usług w tworzeniu dochodu narodowego występuje w Gruzji, a najniższy w Azerbejdżanie.

Analizowane gospodarki państw różnią się też pod względem struktury popytu, tj. udziału spożycia (prywatnego i publicznego) oraz akumulacji w PKB. W państwach o ujemnym saldzie handlu zagranicznego suma dwóch składników wyraźnie przekracza 100\% PKB. Oznacza to, że rozporządzalna masa towarów i usług przeznaczona na cele konsumpcyjne i akumulacji jest większa od wartości produkcji wytworzonej w tych krajach (o nadwyżkę importu nad eksportem). Inaczej kształtuje się sytuacja w państwach z nadwyżką bilansu handlu zagranicznego, zwłaszcza w Azerbejdżanie.

Jak wynika z wyżej przedstawionych danych, Polska i państwa PW są zbiorem państw wyraźnie zróżnicowanych pod względem szeroko rozumianego potencjału gospodarczego i stopnia jego wykorzystania. Różnią się m.in. pod względem stopnia zaangażowania w handlu międzynarodowym (tabela 3).

Tabela 3. Udział Polski i państw PW w handlu międzynarodowym w 2019 roku, w \%

\begin{tabular}{|l|c|c|}
\hline \multicolumn{1}{|c|}{ Wyszczególnienie } & $\begin{array}{c}\text { Udział w eksporcie } \\
\text { światowym }\end{array}$ & $\begin{array}{c}\text { Udział w imporcie } \\
\text { światowym }\end{array}$ \\
\hline Polska & 1,33 & 1,29 \\
\hline Armenia & 0,01 & 0,03 \\
\hline Azerbejdżan & 0,10 & 0,06 \\
\hline Białoruś & 0,17 & 0,21 \\
\hline Gruzja & 0,02 & 0,05 \\
\hline Mołdawia & 0,01 & 0,03 \\
\hline Ukraina & 0,26 & 0,32 \\
\hline
\end{tabular}

Źródło: obliczenia własne na podstawie danych: Trade Statistics for International Business Development, https://www.trademap.org/, [dostęp 3.01.2021] i United Nations Conference on Trade and Development, https://unctadstat.unctad.org/, [dostęp 3.01.2021]

W 2019 roku państwa PW zrealizowały 0,69\% wartości importu światowego, zaś Polska - 1,29\%. W tym samym roku na państwa omawianej grupy przypadało 0,59\% światowego eksportu, podczas gdy udział Polski wynosił 1,33\% światowego eksportu. W sumie występujące między wyżej wymienionymi państwami uderzające dysproporcje, $\mathrm{z}$ różnorodnych zresztą 
względów, nie są dziełem przypadku. Istotne znaczenie ma m.in. uczestnictwo w międzynarodowych przepływach kapitału produkcyjnego, wraz z towarzyszącymi temu przepływami siły roboczej i wiedzy technicznej.

Intensywność międzynarodowych przepływów kapitału, w tym kapitału produkcyjnego, zmienia się w czasie. Za stopień uczestnictwa w międzynarodowych przepływach tego kapitału można przyjąć wstępnie udziały analizowanych państw w jego skumulowanych zasobach po stronie napływów (inflows) i odpływów (outflows) (tabela 4).

Tabela 4. Udział Polski i państw PW w skumulowanych zasobach kapitału produkcyjnego w świecie w 2019 roku, w \%

\begin{tabular}{|l|c|c|}
\hline \multicolumn{1}{|c|}{ Wyszczególnienie } & $\begin{array}{c}\text { Udział w skumulowanych } \\
\text { napływach }\end{array}$ & $\begin{array}{c}\text { Udział w skumulowanych } \\
\text { odpływach }\end{array}$ \\
\hline Polska & 0,859 & 0,162 \\
\hline Armenia & 0,017 & $-0,011$ \\
\hline Azerbejdżan & 0,098 & 0,185 \\
\hline Białoruś & 0,084 & $-0,001$ \\
\hline Gruzja & 0,082 & 0,021 \\
\hline Mołdawia & 0,038 & 0,003 \\
\hline Ukraina & 0,199 & 0,049 \\
\hline
\end{tabular}

Źródło: United Nations Conference on Trade and Development, https://unctadstat.unctad. org/wds/TableViewer/tableView.aspx, [dostęp 12.10.2019]

W 2019 roku udział Polski i państw PW w światowych skumulowanych napływach kapitału produkcyjnego w postaci bezpośrednich inwestycji zagranicznych był marginalny (odpowiednio 0,859\% i 0,518\%). Jeszcze mniejszy był w tymże roku udział Polski i państw PW w światowych skumulowanych odpływach tego kapitału (odpowiednio 0,162\% i 0,248\%). Na tle szeroko rozumianej ekspansji kapitałowej wielu państw świata, były to udziały wręcz śladowe.

Ponadto wśród analizowanych państw Polskę można uznać za lidera zarówno z punktu widzenia szeroko rozumianego potencjału gospodarczego, jak i stopnia jego wykorzystania, w tym stopnia wykorzystania poprzez uczestnictwo w międzynarodowym podziale pracy (tabela 5). 
Tabela 5. Potencjał gospodarczy państw PW i stopień jego wykorzystania na tle Polski w 2019 roku (podstawowe wskaźniki, Polska =100\%)

\begin{tabular}{|c|c|c|c|c|c|c|c|c|}
\hline & & & 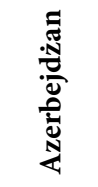 & & 莺 & $\frac{\sqrt{\frac{\pi}{3}}}{\frac{\pi}{0}}$ & $\begin{array}{l}\frac{\pi}{\overparen{\pi}} \\
\frac{\pi}{5} \\
\frac{\pi}{5}\end{array}$ & $\frac{\frac{\pi}{5}}{\frac{0}{0}}$ \\
\hline \multicolumn{2}{|l|}{ Powierzchnia } & 9,51 & 27,70 & 66,39 & 22,29 & 10,83 & 193,02 & 100 \\
\hline \multicolumn{2}{|l|}{ Ludność } & 7,77 & 26,18 & 24,98 & 9,82 & 9,34 & 117,49 & 100 \\
\hline \multicolumn{2}{|l|}{ PKB } & 2,29 & 8,06 & 10,59 & 2,93 & 2,01 & 25,81 & 100 \\
\hline \multirow{2}{*}{$\begin{array}{l}\text { Uczestnictwo } \\
\text { w handlu } \\
\text { towarami }\end{array}$} & Import & 2,06 & 4,87 & 15,99 & 3,86 & 2,37 & 24,63 & 100 \\
\hline & Eksport & 1,04 & 7,80 & 13,02 & 1,51 & 1,10 & 19,87 & 100 \\
\hline \multirow{2}{*}{$\begin{array}{l}\text { Uczestnictwo } \\
\text { w handlu } \\
\text { usługami }\end{array}$} & Import & 5,29 & 14,54 & 13,30 & 5,54 & 2,69 & 35,02 & 100 \\
\hline & Eksport & 3,33 & 5,22 & 13,35 & 6,39 & 2,13 & 24,03 & 100 \\
\hline \multirow{2}{*}{$\begin{array}{l}\text { Skumulo- } \\
\text { wane zasoby } \\
\text { kapitału } \\
\text { produkcyjnego }\end{array}$} & Napływ & 1,92 & 11,38 & 9,78 & 9,59 & 4,45 & 23,22 & 100 \\
\hline & Odpływ & $-6,69$ & 114,04 & $-0,32$ & 13,20 & 1,99 & 30,39 & 100 \\
\hline
\end{tabular}

Źródło: obliczenia własne na podstawie: World Bank, https://databank.worldbank.org/, [dostęp 10.12.2020]; Trade Map i United Nations Conference on Trade and Development, https://unctadstat.unctad.org/wds/TableViewer/tableView.aspx, [dostęp 12.12.2020]

Z punktu widzenia rozmiarów potencjału gospodarczego i stopnia jego wykorzystania Polska i państwa PW nie stanowią grupy jednorodnej. Państwa PW można podzielić na dwie grupy. Przede wszystkim chodzi, po pierwsze, o Ukrainę dysponującą znacznym potencjałem, przewyższającym potencjał gospodarczy Polski, ale zarazem wykorzystującą tenże potencjał mniej efektywnie niż Polska. Po drugie, to państwa dysponujące relatywnie niewielkim potencjałem i nie wykorzystujące go w pełni efektywnie. $\mathrm{Na}$ przykład Mołdawia i Białoruś realizują politykę ściśle autonomicznego rozwoju gospodarczego. W Armenii z kolei wzrost gospodarczy jest uzależniony głównie od sektora budownictwa, rolnictwa i przemysłu wydobywczego, a w mniejszym stopniu od sfery usług. Taki stan rzeczy powoduje, że gospodarkę Armenii cechują spore dysproporcje, nawet w stosunku do gospodarki 
Białorusi [Экономика Армении..., 2018]. Natomiast gospodarka Azerbejdżanu jest dotknięta problemem „,choroby holenderskiej”, ponieważ jej wzrost jest uzależniony od rozwijania sektora wydobycia i dystrybucji ropy naftowej, a w mniejszym stopniu od generowania dochodów w nie surowcowych sektorach gospodarki [Азербайждан: ресурсная модель..., 2018, s. 9]. Z kolei rozwój gospodarczy Gruzji jest uzależniony od finansowania zewnętrznego, ale nie jest to finansowanie zadłużeniowe. Pomimo to, Gruzji nie udaje się rozwinąć realnego sektora gospodarki, ponieważ prawie wszystkie środki są skoncentrowane w sektorze budownictwa i handlu [Mekvabishvili, Beridze, 2018, s. 21-29].

\section{Zarys pozaekonomicznych uwarunkowań rozwoju powiązań gospodarczych Polski z państwami PW}

Pozaekonomiczne uwarunkowania rozwoju powiązań gospodarczych Polski z państwami PW można ogólnie podzielić na polityczne, instytucjonalno-instrumentalne i pozostałe, $w$ tym kulturowe.

Aktualnie stosunki między Polską a państwami PW układają się różnie w dwóch odmiennych grupach krajów. Pierwszą grupę tworzą Gruzja, Mołdawia i Ukraina, które podpisały porozumienie z Unią Europejską o utworzeniu strefy wolnego handlu. Drugą grupę tworzą Armenia, Azerbejdżan i Białoruś, które bazują na nowych Umowach regulujących współpracę gospodarczą z UE lub na dotychczasowych Układach z połowy lat 90. ubiegłego wieku.

Na przestrzeni tych 30 lat stosunki polityczne między Polską a państwami Kaukazu Południowego (Armenią, Azerbejdżanem i Gruzją) uznaje się za pozytywne, a w relacjach z poszczególnymi krajami nie zanotowano żadnych problemów. Chociaż Polska od lat popiera przemiany zachodzące w tych krajach, ten kierunek polskiej polityki zagranicznej przez lata nie jest uznawany za priorytetowy.

Gruzja, jako pierwsze państwo Kaukazu Południowego, została wyeksponowana w polityce zagranicznej Polski w 1993 roku. Wiązało się to z podpisaniem w Tbilisi 20 kwietnia 1993 roku Traktatu o przyjaźni i wspótpracy między $R P$ a Gruzją, który był pierwszą i jedyną tego typu umową ramową zawartą z państwem Kaukazu Południowego [Traktat sporzadzony w Tbilisi..., 1999]. W tym okresie Armenia i Azerbejdżan nie zajęły istotnego miejsca w polskiej 
polityce zagranicznej. Jednak z czasem jej założenia znalazły odzwierciedlenie w bilateralnych umowach sektorowych, które Polska podpisała z tymi państwami w połowie lat 90. XX wieku [Armenia. Informator ekonomiczny, 2019; Azerbejdżan. Informator ekonomiczny, 2019]. Działania te odpowiadały polskim planom intensyfikacji bilateralnych stosunków i dotyczyły odbudowy zerwanych bądź osłabionych więzi gospodarczych oraz rozwoju współpracy w nowych dziedzinach, w tym poprzez budowę sieci przedstawicielstw dyplomatyczno-konsularnych [Armenia, 2019; Azerbejdżan, 2019; Gruzja, 2019] ${ }^{1}$. Pod koniec lat 90., w związku ze zbliżającym się członkostwem Polski w NATO i Unii Europejskiej, można było zaobserwować starania polskich władz w zakresie silniejszego umocowania Armenii, Azerbejdżanu i Gruzji w priorytetach polityki zagranicznej. Do istotnych zadań związanych z tymi państwami zaliczono wymiar społeczny, konflikty w regionie i bezpieczeństwo energetyczne (Geremek, 1998). Wskutek takiego postawienia sprawy wzrosła pozycja Azerbejdżanu jako kraju posiadającego surowce i Gruzji jako kraju tranzytowego. Pomimo to, do połowy pierwszej dekady XXI wieku nie odnotowano zdecydowanego przełomu w założeniach polityki zagranicznej Polski wobec Armenii, Azerbejdżanu i Gruzji (Czechowska, 2017, s. 276) ${ }^{2}$.

Przełom w relacjach z państwami Kaukazu Południowego nastąpił po uzyskaniu przez Polskę członkostwa w Unii Europejskiej. To spowodowało, że Polska podjęła próbę trwałego włączenia trzech państw do orbity swojej polityki zagranicznej i skoordynowania jej z polityką Unii Europejskiej. Przychylny klimat stworzyła w 2003 roku rewolucja róż w Gruzji ze zwróceniem uwagi także na Armenię i Azerbejdżan, jako szansę na reorientację ich polityki. Podejmowane wówczas przez Polskę działania były ukierunkowane

1 Armenia: Polska nawiązała stosunki dyplomatyczne z Republiką Armenii 26 II 1992 r., a wymagane procedury formalne zakończyły się w listopadzie $1992 \mathrm{r}$. Ambasada Armenii w Warszawie otwarta została 6 IV 1998 r., zaś Ambasada Polska w Erywaniu - 28 II 2000 r.; Azerbejdżan: Stosunki dyplomatyczne między Polską a Azerbejdżanem zostały nawiązane 21 II 1992 r. Polska otworzyła ambasadę w Baku w 1998 r., a Azerbejdżan otworzył swoją ambasadę 30 VIII 2004 r.; Gruzja: Stosunki dyplomatyczne między Polską a Gruzją zostały nawiązane 28 IV 1992 r. Ambasadę RP w Tbilisi powołano 20 XI 1995 r., a jej otwarcie nastąpiło 1 XI 1997 r. Ambasada Gruzji w Warszawie została otwarta w 2004 r.

${ }^{2}$ Na początku XXI wieku państwa Kaukazu Południowego określono jako partnerów perspektywicznych (chociaż są one geograficznie odległe), którzy ze względu na posiadany potencjał surowcowy mogą pomóc w realizacji polskich interesów narodowych. 
na proces stabilizacji w regionie Kaukazu Południowego oraz wspieranie suwerenności i transformacji wewnętrznej tych państw (Gomółka, Borucińska-Dereszkiewicz, 2015, s. 155-156).

Wzrost roli państw Kaukazu Południowego od 2005 roku wiązał się z włączaniem położonych tam państw do programów partii politycznych, które coraz bardziej akcentowały znaczenie relacji z Armenią, Azerbejdżanem i Gruzją, ale nie dotyczyło to wszystkich państw w jednakowym stopniu. Nadanie coraz większej roli stosunkom Polski z państwami Kaukazu Południowego miało wyrażać się szczególnie w aktywności na rzecz wspierania procesu transformacji ustrojowej Gruzji oraz jej starań o członkostwo w NATO i w Unii Europejskiej. Na drugim miejscu ulokowano Azerbejdżan ze względu na kwestie energetyczne (Gomółka, Borucińska-Dereszkiewicz, 2015, s. 159-161). Mniejsze zainteresowanie wykazywano względem Armenii, która w drugiej dekadzie XXI wieku nadal nie posiadała statusu ważnego partnera. W polityce zagranicznej Armenii obserwowano proces konceptualizacji, który zdominował wybór jej dwukierunkowego charakteru, czyli jednoczesnego rozwoju stosunków ze Wschodem i Zachodem. Jednak duże uzależnienie Armenii od Rosji skutkuje utrudnieniami w prowadzeniu zrównoważonej polityki dwukierunkowej. Dodatkowo negatywny wpływ ma pełna akcesja Armenii w Euroazjatyckiej Unii Gospodarczej w 2015 roku. Dla przyszłych stosunków polsko-armeńskich istotne znaczenie ma zawarcie nowej umowy ramowej o pogłębionej współpracy unijno-armeńskiej (Borucińska-Dereszkiewicz, 2017, s. 148-149).

Relacje polityczne Polski z Białorusią, na tle kontaktów z innymi krajami programu PW, wyróżniają się stosunkowo niską aktywnością. Jednakże, na początku lat 90. XX wieku Polska po ogłoszeniu przez Białoruś niepodległości oficjalnie nawiązała z nią 2 marca 1992 roku stosunki dyplomatyczne, a 23 kwietnia 1992 roku oba kraje połączył Traktat o dobrym sąsiedztwie i przyjaznej współpracy oraz szereg innych umów [Białoruś, 2019]. Polska od początku niepodległości Białorusi była żywotnie zainteresowana ugruntowaniem i rozwojem tego niepodległego podmiotu oraz dążyła do tworzenia warunków sprzyjających współpracy gospodarczej między państwami (Czechowska, 2017, s. 108). W połowie lat 90. Polska była żywo zainteresowana podniesieniem na wyższy poziom współpracy ekonomicznej polsko-białoruskiej we wszystkich dziedzinach (Czechowska, 2017, s. 132). Natomiast 
współpraca polityczna między Polską a Białorusią od tego momentu zaczęła napotykać trudności ze względu na jednokierunkowy charakter polityki zagranicznej Białorusi i chęć pogłębienia integracji z Rosją. Pod koniec lat 90. Polska uznała, że zakres i charakter jej stosunków z Białorusią będzie zależał od rozwoju sytuacji w tym kraju i jego stanowiska w ważnych kwestiach międzynarodowych. Jednocześnie zostało zaznaczone, że Polska nie jest zainteresowana samoizolacją Białorusi (Czechowska, 2017, s. 210). Tak samo na początku XXI wieku Polska uznała, że treść i ranga oficjalnego dialogu politycznego z Białorusią będzie zależała od rozwoju sytuacji wewnętrznej w tym kraju oraz od stosunku do kluczowych spraw międzynarodowych (Czechowska, 2017, s. 230). Aktualnie na stan stosunków Polski i Białorusi wpływa sytuacja wewnętrzna $\mathrm{w}$ republice, skutkująca m.in. międzynarodową samoizolacją tego kraju (Czechowska, 2017, s. 297-298). Wyzwaniem dla polskiej dyplomacji pozostaje wypracowanie modelu postępowania, pozwalającego na realizację żywotnie ważnych dla Polski interesów przy jednoczesnym zachowaniu krytycznego i wstrzemięźliwego stosunku wobec rządzącego Białorusią obozu Aleksandra Łukaszenki (Czachor, 2013, s. 265).

Stosunki polityczne między Polską i Mołdawią są tradycyjnie bardzo dobre. Polska jest odbierana przez władze Mołdawii jako partner o znaczeniu strategicznym ze względu na europejskie aspiracje tego kraju. Przesłanka ta warunkuje aktywny dialog polityczny i częstą wymianę wizyt przedstawicieli elit politycznych (Kotulewicz, 2011, s. 203-211; Kotulewicz, 2014, s. 275-288). Ponadto, wpływ na zacieśnienie współpracy Mołdawii z Polską mają zmiany na scenie politycznej i rozwój sytuacji politycznej w republice. Na przestrzeni prawie trzydziestu lat Polska i Mołdawia rozszerzyły współpracę od poziomu rządowego do poziomu administracji rządowej. Na obecnym etapie wpływ na rozwój stosunków polsko-mołdawskich ma program Partnerstwo Wschodnie, m.in. przez fakt, że współczesna Mołdawia w dalszym ciągu jest objęta wewnętrznym procesem transformacji, co z kolei generuje kierunki polityki zagranicznej republiki.

Natomiast o stosunkach polsko-ukraińskich zwykle mówi się jako o rzeczywistości trudnej, złożonej, momentami historycznie bolesnej, aczkolwiek nie brakuje przykładów świadczących o dobrej współpracy między państwami. Po rozpadzie ZSRR Polska postawiła na dobre ułożenie stosunków z Ukrainą i dążyła do zbliżenia między krajami (Czechowska, 2017, s. 67). 
Przejawem tych działań było nie tylko uznanie niepodległości Ukrainy, ale i zawarcie w dniu 18 maja 1992 r. Traktatu o dobrym sasiedztwie, przyjaznych stosunkach $i$ wspótpracy (Ukraina, 2019). Polska niejednokrotnie wyrażała stanowisko, że współpraca z Ukrainą powinna służyć umacnianiu niepodległego oraz demokratycznego państwa ukraińskiego. Stosunki polsko-ukraińskie są ważnym czynnikiem stabilności i bezpieczeństwa w naszym regionie i całej Europie (Czechowska, 2017, s. 90-92). W marcu 1994 roku Polska potwierdziła, że stosunki z Ukrainą mają charakter „ścisłego" partnerstwa oraz wspierała transformację polityczną i gospodarczą na Ukrainie (Czechowska, 2017, s. 109). Od 1996 roku jednym z przejawów okazywanego Ukrainie przez Polskę wsparcia było niesienie pomocy w kształceniu kadr administracyjnych i gospodarczych (Czechowska, 2017, s. 149). Ważnym wydarzeniem w stosunkach polsko-ukraińskich było podpisanie w maju 1997 roku Wspólnego oświadczenia o zgodzie i pojednaniu, w którym uczczono pamięć ofiar konfliktów polsko-ukraińskich (Ukraina, 2019). Podpisanie tego dokumentu przyczyniło się do strategicznego partnerstwa Ukrainy i Polski od końca lat 90. XX (Czechowska, 2017, s. 209-210) do czasów współczesnych. Obecnie na Ukrainie zachodzą zmiany, które zostały zainicjowane w wyniku pomarańczowej rewolucji i rewolucji godności. Te wydarzenia w przyszłości powinny zaowocować ukształtowaniem na Ukrainie narodu politycznego oraz społeczeństwa obywatelskiego i będą wpływały na relacje tego kraju z najbliższym sąsiedztwem. Jak widać, stosunki Polski i Ukrainy rozwijają się dynamicznie, a dobrym tego przykładem w ciągu ostatnich dziesięciu lat jest wspólna organizacja turnieju EURO 2012. Obecnie Polska, jako członek UE, nieustanie popiera dążenia Ukrainy do integracji europejskiej.

Ponadto, przedstawiciele państw $\mathrm{PW}$, o których mowa, uczestniczą w pracach wielu podstawowych organizacji międzynarodowych, w tym wyspecjalizowanych organizacji systemu ONZ oraz podstawowych organizacji gospodarczych, jak: Międzynarodowy Fundusz Walutowy, Międzynarodowy Bank Odbudowy i Rozwoju i Światowa Organizacja Handlu.

Aktualne instytucjonalno-instrumentalne uwarunkowania rozwoju współpracy gospodarczej Polski z krajami PW są w dużej mierze pochodną uwarunkowań politycznych. 


\section{Dotychczasowy rozwój i aktualny stan powiązań gospodarczych Polski z państwami PW}

Państwa PW nadał zajmują odległe miejsca wśród partnerów handlowych Polski. Dotyczy to zarówno eksportu, jak i importu (tabela 6).

W analizowanym okresie udział państw PW w imporcie Polski, pomimo że wzrósł ponad dziewięciokrotnie, stanowił tylko 1,66\% ogółu importu Polski. Wśród państw PW znaczenie dla Polski miał import z Ukrainy, natomiast w przypadku pozostałych państw stanowił margines.

W latach 1995-2018 obserwowano także wzrost znaczenia eksportu Polski do państw PW. Udział państw PW w eksporcie z Polski wzrósł ponad ośmiokrotnie, jednak i on stanowił tylko 2,51\% ogółu eksportu Polski. Wśród państw PW zauważalne znaczenie miał eksport z Polski na Ukrainę, do Mołdawii i na Białoruś. Państwa Kaukazu Południowego w polskim eksporcie nadal uczestniczą w niewielkim stopniu.

Natomiast w latach 1995-2019 w państwach PW obserwowano wzrost znaczenia handlu zagranicznego z Polską. Dla takich państw PW, jak Ukraina, Mołdawia i Białoruś, Polska jest jednym z głównych partnerów handlowych. Na szczególną uwagę zasługuje Ukraina, dla której obecnie Polska jest rynkiem eksportowym numer jeden, chociaż w 2019 roku przypadało na nią tylko 4,37\% ogółu ukraińskiego eksportu. Dla Białorusi aktualnie Polska jest piątym partnerem handlowym po stronie importu i trzecim po stronie eksportu. Udział Polski w białoruskim eksporcie w 2019 roku wynosił 3,31\% oraz w białoruskim imporcie - 3,70\%. Natomiast dla Mołdawii Polska jest szóstym partnerem po stronie eksportu i ósmym po stronie importu. Pomimo wzrostu obrotów handlowych, udział Polski w handlu zagranicznym państw Kaukazu Południowego nadal jest niewielki. Podsumowując, należy zauważyć, że w sumie eksport z państw PW do Polski był o 25\% niższy od eksportu z Polski do państw PW.

Średnioroczna dynamika wzrostu polskiego eksportu na rynek państw PW w latach 1995-2019 wynosiła 54,82\% i była wyższa od średniorocznej dynamiki eksportu państw PW na rynek polski o 31,73 p.p. (tabela 8). Stopa wzrostu polskiego eksportu na rynek państw PW w 2019 roku, w stosunku do początkowego roku analizy, wyniosła $825 \%$, podczas gdy stopa wzrostu eksportu z państw PW do na rynek Polski była równa $773 \%$. 


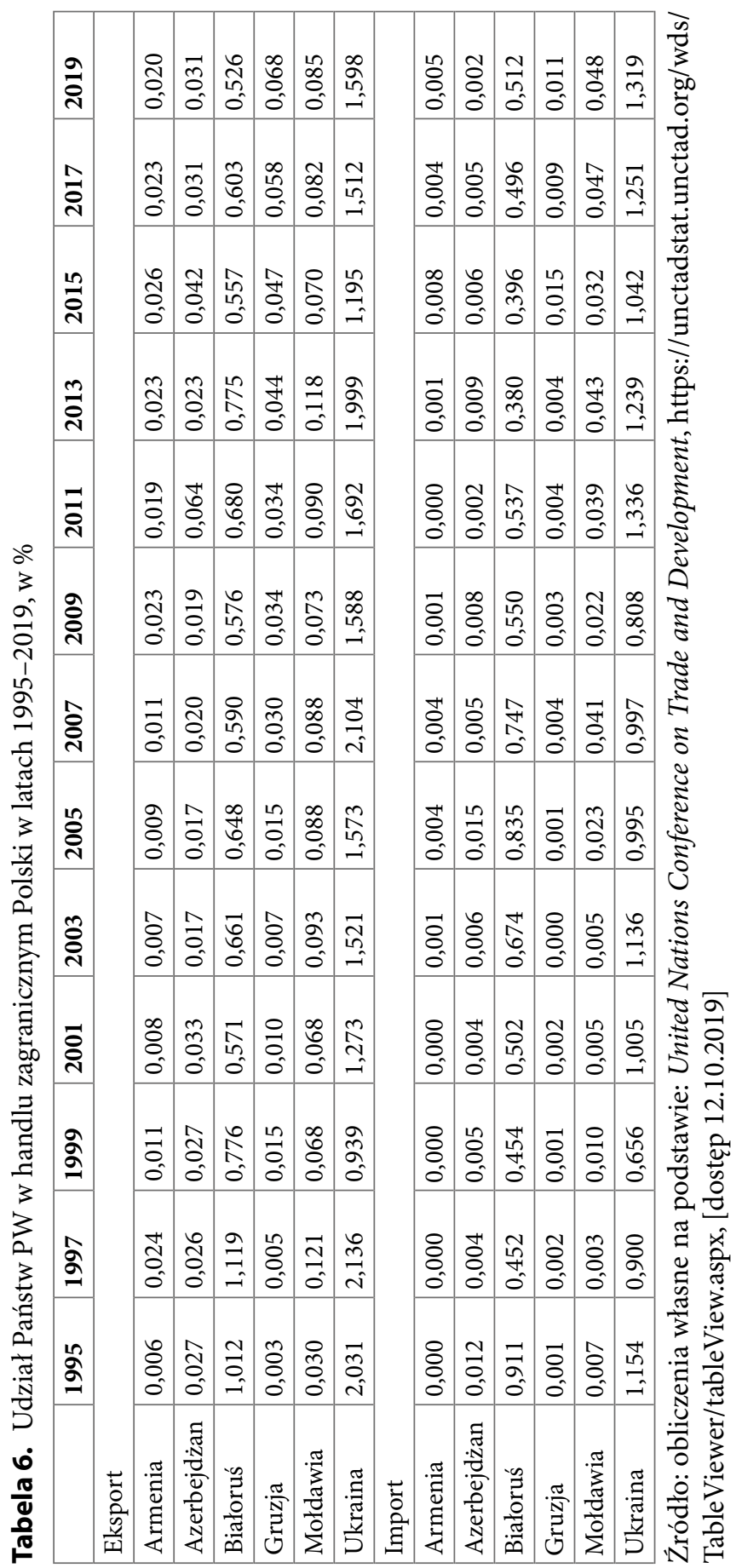




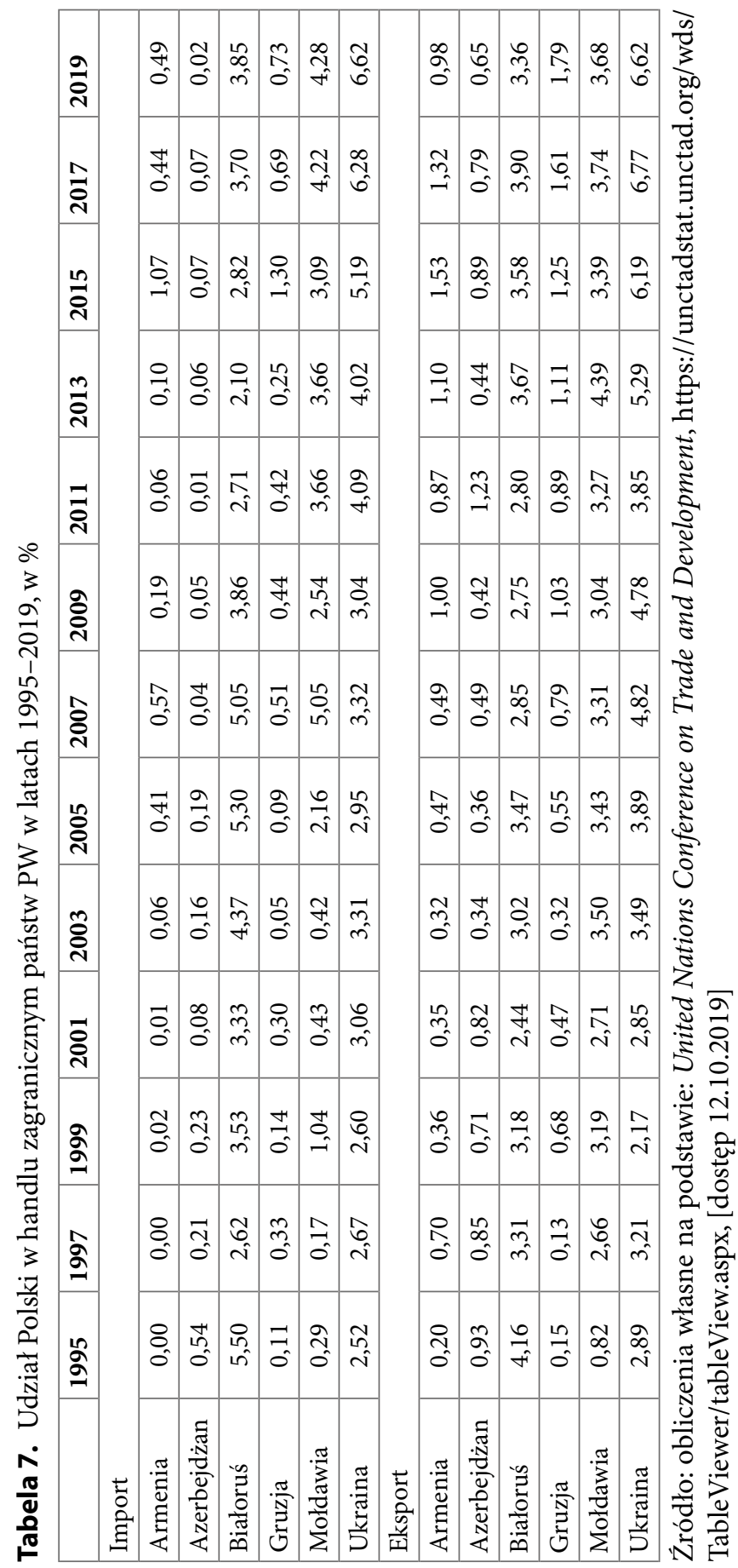




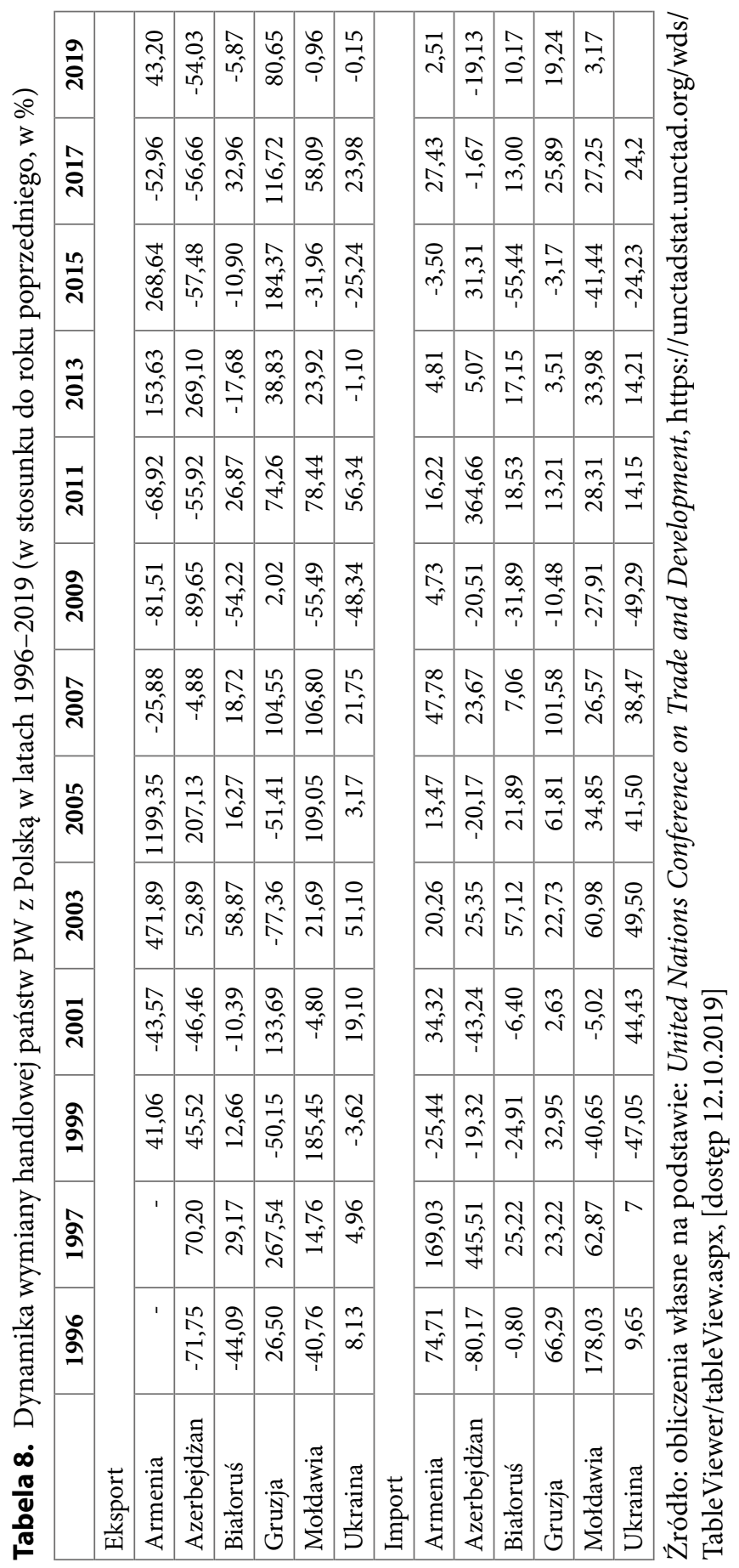


Jak wynika $z$ danych zawartych w tabeli 6 . cały czas mamy do czynienia z kreacją nowych strumieni handlu między Polską a państwami PW, co wpływa pozytywnie - choć w ograniczonym i zróżnicowanym stopniu - na rozwój gospodarczy analizowanych państw. Inną kwestią jest niewykorzystana możliwość w warunkach znaczniejszej wewnątrzgałęziowej komplementarności struktury wymiany między tymi krajami i bardziej intensywnej wymiany mobilnych czynników wytwórczych.

W analizowanym przedziale czasowym towarowa i rodzajowa struktura handlu między Polską a państwami PW wyraźnie się zmieniała.

Tabela 9. Wskaźniki ujawnionych przewag względnych RCA dla handlu Polski z państwami $P W$ w wybranych latach okresu 1995-2019

\begin{tabular}{|c|c|c|c|c|c|c|c|}
\hline & \multirow[b]{2}{*}{ Lata } & \multicolumn{6}{|c|}{ Partner handlowy } \\
\hline & & Armenia & $\begin{array}{c}\text { Azerbej- } \\
\text { dżan }\end{array}$ & Białoruś & Gruzja & Mołdawia & Ukraina \\
\hline \multirow{3}{*}{$\begin{array}{l}\text { surowco- } \\
\text { chłonne }\end{array}$} & 1995 & - & $-2,36$ & 0,87 & 0,96 & 1,23 & 0,18 \\
\hline & 2018 & $-0,56$ & 0,68 & 1,16 & 0,01 & 0,06 & 1,02 \\
\hline & 2019 & $-0,40$ & 2,73 & 1,07 & $-0,55$ & 0,75 & 1,46 \\
\hline \multirow{3}{*}{$\begin{array}{l}\text { pracochłon- } \\
\text { ne }\end{array}$} & 1995 & - & 4,01 & $-0,18$ & $-0,47$ & $-2,22$ & $-1,03$ \\
\hline & 2018 & $-0,87$ & $-2,09$ & 0,03 & $-0,16$ & $-0,54$ & $-0,44$ \\
\hline & 2019 & $-1,33$ & $-2,14$ & 0,12 & 0,35 & $-0,54$ & $-0,07$ \\
\hline \multirow{3}{*}{$\begin{array}{l}\text { kapita- } \\
\text { łochłonne }\end{array}$} & 1995 & - & - & $-1,32$ & - & 0,81 & $-0,20$ \\
\hline & 2018 & 1,33 & $-2,47$ & $-0,38$ & 0,71 & 1,22 & 0,18 \\
\hline & 2019 & 1,07 & $-1,29$ & $-0,30$ & 0,38 & 0,69 & 0,35 \\
\hline \multirow{3}{*}{$\begin{array}{l}\text { techno- } \\
\text { logicznie } \\
\text { intensywne } \\
\text { łatwe do } \\
\text { imitowania }\end{array}$} & 1995 & - & - & $-0,07$ & - & - & 0,87 \\
\hline & 2018 & $-2,11$ & 2,01 & $-1,45$ & $-2,22$ & $-2,73$ & $-0,29$ \\
\hline & 2019 & $-4,58$ & - & $-2,12$ & $-1,20$ & $-2,49$ & 0,13 \\
\hline \multirow{3}{*}{$\begin{array}{l}\text { techno- } \\
\text { logicznie } \\
\text { intensywne } \\
\text { trudne do } \\
\text { imitowania }\end{array}$} & 1995 & - & - & $-0,86$ & - & - & $-0,16$ \\
\hline & 2018 & $-2,95$ & $-12,21$ & $-2,12$ & $-0,93$ & $-0,83$ & $-1,16$ \\
\hline & 2019 & $-4,22$ & $-3,26$ & $-1,50$ & $-0,76$ & $-0,59$ & $-0,67$ \\
\hline \multirow{3}{*}{$\begin{array}{l}\text { Średnia } \\
\text { zwykła }\end{array}$} & 1995 & - & - & $-0,31$ & - & - & $-0,07$ \\
\hline & 2018 & $-2,8$ & $-0,82$ & $-0,54$ & $-0,52$ & $-0,56$ & $-0,14$ \\
\hline & 2019 & $-1,89$ & $-0,79$ & $-0,55$ & $-0,51$ & $-0,44$ & 0,24 \\
\hline
\end{tabular}

Źródło: obliczenia własne na podstawie: United Nations Conference on Trade and Development, https://unctadstat.unctad.org/wds/TableViewer/tableView.aspx, [dostęp 12.10.2019] 
Wartość wskaźnika RCA większa od zera świadczy o występowaniu ujawnionej przewagi względnej i wskazuje na intensywność tej przewagi. W przypadku wskaźników RCA mniejszych od zera mamy do czynienia z brakiem tego typu przewagi. Z powyżej uzyskanych danych wynika, że handel Polski z państwami PW jest w większym stopniu wymianą typu międzygałęziowego. Taki układ struktury wymiany nie ułatwia procesu przechodzenia do wymiany o charakterze wewnątrzgałęziowym (tabela 10).

Tabela 10. Wskaźniki intensywności handlu wewnątrzgałęziowego IIT w handlu Polski z państwami PW w wybranych latach okresu 1995-2019

\begin{tabular}{|l|l|l|c|c|c|c|c|}
\hline & Lata & \multicolumn{7}{|c|}{ Partner handlowy } \\
\cline { 3 - 8 } & & Armenia & $\begin{array}{c}\text { Azerbej- } \\
\text { dżan }\end{array}$ & Białoruś & Gruzja & Mołdawia & Ukraina \\
\hline \multirow{3}{*}{ surowcochłonne } & 1995 & 0 & 0,04 & 0,59 & 0,57 & 0,82 & 0,64 \\
& 2018 & 0,26 & 0,50 & 0,53 & 0,26 & 0,89 & 0,77 \\
& 2019 & 0,37 & 0,98 & 0,68 & 0,18 & 0,87 & 0,79 \\
\hline & 1995 & 0 & 0,15 & 0,91 & 0,17 & 0,04 & 0,25 \\
pracochłonne & 2018 & 0,20 & 0,04 & 0,94 & 0,23 & 0,61 & 0,54 \\
& 2019 & 0,16 & 0,02 & 0,86 & 0,40 & 0,53 & 0,50 \\
\hline & 1995 & - & 0 & 0,42 & 0 & 0,62 & 0,49 \\
kapitałochłonne & 2018 & 0,99 & 0,03 & 0,75 & 0,47 & 0,56 & 0,82 \\
& 2019 & 0,99 & 0,04 & 0,67 & 0,41 & 0,90 & 0,68 \\
\hline technologicznie & 1995 & - & 0 & 0,96 & 0 & 0 & 0,97 \\
intensywne łatwe & 2018 & 0,06 & 0,88 & 0,37 & 0,03 & 0,09 & 0,60 \\
do imitowania & 2019 & 0,01 & - & 0,15 & 0,10 & 0,10 & 0,58 \\
\hline technologicznie & 1995 & 0 & 0 & 0,59 & 0 & 0 & 0,50 \\
intensywne trud- & 2018 & 0,03 & 0 & 0,19 & 0,11 & 0,50 & 0,31 \\
ne do imitowania & 2019 & 0,01 & 0,01 & 0,26 & 0,15 & 0,51 & 0,31 \\
\hline \multirow{2}{*}{ Śnednia zwykła } & 1995 & - & 0,04 & 0,69 & 0,15 & 0,30 & 0,57 \\
& 2018 & 0,31 & 0,29 & 0,55 & 0,22 & 0,53 & 0,61 \\
& 2019 & 0,24 & 0,21 & 0,52 & 0,25 & 0,58 & 0,57 \\
\hline
\end{tabular}

Źródło: obliczenia własne na podstawie: United Nations Conference on Trade and Development, https://unctadstat.unctad.org/wds/TableViewer/tableView.aspx, [dostęp 12.10.2019]

Ze względu na specyficzny układ struktury handlu Polski z państwami PW (dominacja w imporcie surowców i półproduktów, zaś w eksporcie Polski wielu tradycyjnych pozycji z zakresu artykułów rolno-spożywczych, surowców i półproduktów) intensywność handlu wewnątrzgałęziowego między Polską a państwami PW kształtowała się na niskim poziomie i zmieniała się właściwie z roku na rok. Przyczyną takiego stanu rzeczy była niska i zmieniająca 
się intensywność przepływów podstawowych czynników wytwórczych (siły roboczej, kapitału i wiedzy technicznej) między Polską i państwami PW. Kolejną przyczyną wydaje się być mniej lub bardziej wyraźny brak zrównoważenia obrotów handlowych Polski z państwami PW. Dotyczyło to zwłaszcza kształtowania się salda bilansu handlowego (tabela 11).

Tabela 11. Udział deficytu (nadwyżki) bilansu handlowego Polski w wartości jej eksportu w wymianie handlowej z państwami PW w latach 1995-2019, w \%

\begin{tabular}{|c|c|c|c|c|c|c|}
\hline & Armenia & $\begin{array}{c}\text { Azerbej- } \\
\text { dżan }\end{array}$ & Białoruś & Gruzja & Mołdawia & Ukraina \\
\hline 1995 & 100 & 72,86 & 0,93 & 84,66 & 80,11 & 60,85 \\
\hline 1996 & 100 & 97,67 & 5,51 & 94,38 & 94,94 & 57,20 \\
\hline 1997 & 100 & 98,73 & 30,84 & 93,08 & 95,94 & 65,57 \\
\hline 1998 & 100 & 97,95 & 35,90 & 94,05 & 95,93 & 65,28 \\
\hline 1999 & 100 & 91,50 & 28,77 & 95,95 & 81,99 & 51,85 \\
\hline 2000 & 100 & 87,96 & 33,48 & 92,60 & 88,02 & 38,88 \\
\hline 2001 & 100 & 93,27 & 44,62 & 86,46 & 87,99 & 54,45 \\
\hline 2002 & 100 & 84,43 & 7,01 & 74,51 & 92,22 & 57,92 \\
\hline 2003 & 80,85 & 82,74 & $-2,32$ & 61,61 & 95,64 & 51,81 \\
\hline 2004 & 84,51 & 84,39 & $-23,60$ & 73,56 & 75,01 & 48,68 \\
\hline 2005 & $-36,34$ & 78,94 & $-35,65$ & 69,96 & 71,42 & 60,55 \\
\hline 2006 & $-25,69$ & 90,72 & $-10,35$ & 85,83 & 71,23 & 66,75 \\
\hline 2007 & 18,00 & 93,59 & $-1,65$ & 88,53 & 30,05 & 69,27 \\
\hline 2008 & 47,95 & $-59,33$ & 18,08 & 71,88 & 29,37 & 63,46 \\
\hline 2009 & 85,23 & 87,58 & 32,57 & 84,87 & 69,26 & 66,41 \\
\hline 2010 & 79,51 & 92,28 & 47,89 & 82,18 & 67,33 & 53,62 \\
\hline 2011 & 95,29 & 96,58 & 26,94 & 83,50 & 54,48 & 40,48 \\
\hline 2012 & 98,15 & 96,47 & 51,02 & 88,99 & 63,15 & 51,72 \\
\hline 2013 & 93,73 & 84,50 & 67,84 & 80,89 & 72,63 & 61,17 \\
\hline 2014 & 83,15 & 77,63 & 60,50 & 80,17 & 60,05 & 45,66 \\
\hline 2015 & 67,93 & 88,24 & 37,61 & 52,37 & 57,20 & 48,57 \\
\hline 2016 & 30,84 & 31,22 & 41,27 & 89,18 & 59,13 & 47,51 \\
\hline 2017 & 71,46 & 82,06 & 27,95 & 84,00 & 37,02 & 49,96 \\
\hline 2018 & 73,58 & 82,85 & 12,90 & 84,99 & 24,58 & 42,47 \\
\hline 2019 & 66,59 & 93,22 & 32,82 & 82,70 & 38,63 & 64,08 \\
\hline $\begin{array}{l}\text { Średnia } \\
\text { zwykła }\end{array}$ & 72,59 & 80,32 & 22,84 & 82,44 & 67,73 & 55,37 \\
\hline
\end{tabular}

Źródło: obliczenia własne na podstawie: United Nations Conference on Trade and Development, https://unctadstat.unctad.org/wds/TableViewer/tableView.aspx, [dostęp 12.10.2019] 
Handel między Polska a państwami PW nosił i nosi w dalszym ciągu znamiona wymiany realizowanej zgodnie z doktryną merkantylistyczną. W handlu w państwami tej grupy Polska odnotowuje z reguły znaczne nadwyżki. Istotny jest także wpływ nadal mało zdywersyfikowanej struktury podaży eksportowej Polski na rynki analizowanych krajów i relatywnie niewysoki stopień jej dopasowania do struktury popytu importowego partnerów (tabela 12).

Tabela 12. Wskaźnik stopnia dopasowania struktury podaży eksportowej Polski do struktury popytu importowego Państw PW w latach 1995-2019

\begin{tabular}{|l|c|c|c|c|c|c|}
\hline & $\begin{array}{c}\text { Polska- } \\
\text {-Armenia }\end{array}$ & $\begin{array}{c}\text { Polska- } \\
\text {-Azerbejdzan }\end{array}$ & $\begin{array}{c}\text { Polska- } \\
\text {-Białoruś }\end{array}$ & $\begin{array}{c}\text { Polska- } \\
\text {-Gruzja }\end{array}$ & $\begin{array}{c}\text { Polska- } \\
\text {-Mołdawia }\end{array}$ & $\begin{array}{c}\text { Polska- } \\
\text {-Ukraina }\end{array}$ \\
\hline 1995 & 0,42 & 0,72 & 0,79 & 0,60 & 0,63 & 0,79 \\
\hline 1996 & 0,57 & 0,57 & 0,70 & 0,53 & 0,59 & 0,62 \\
\hline 1997 & 0,49 & 0,51 & 0,72 & 0,49 & 0,56 & 0,54 \\
\hline 1998 & 0,60 & 0,54 & 0,72 & 0,40 & 0,47 & 0,57 \\
\hline 1999 & 0,64 & 0,55 & 0,72 & 0,45 & 0,54 & 0,48 \\
\hline 2000 & 0,49 & 0,79 & 0,63 & 0,44 & 0,51 & 0,52 \\
\hline 2001 & 0,55 & 0,64 & 0,66 & 0,50 & 0,65 & 0,56 \\
\hline 2002 & 0,53 & 0,59 & 0,66 & 0,50 & 0,68 & 0,58 \\
\hline 2003 & 0,49 & 0,62 & 0,66 & 0,38 & 0,64 & 0,63 \\
\hline 2004 & 0,58 & 0,75 & 0,67 & 0,69 & 0,70 & 0,61 \\
\hline 2005 & 0,65 & 0,59 & 0,62 & 0,65 & 0,71 & 0,67 \\
\hline 2006 & 0,75 & 0,59 & 0,62 & 0,70 & 0,72 & 0,71 \\
\hline 2007 & 0,73 & 0,75 & 0,61 & 0,57 & 0,75 & 0,72 \\
\hline 2008 & 0,77 & 0,85 & 0,61 & 0,59 & 0,72 & 0,73 \\
\hline 2009 & 0,80 & 0,72 & 0,57 & 0,62 & 0,73 & 0,68 \\
\hline 2010 & 0,79 & 0,82 & 0,61 & 0,66 & 0,77 & 0,68 \\
\hline 2011 & 0,79 & 0,85 & 0,55 & 0,67 & 0,79 & 0,67 \\
\hline 2012 & 0,74 & 0,79 & 0,59 & 0,73 & 0,79 & 0,75 \\
\hline 2013 & 0,76 & 0,74 & 0,68 & 0,71 & 0,65 & 0,79 \\
\hline 2014 & 0,77 & 0,80 & 0,67 & 0,70 & 0,68 & 0,79 \\
\hline 2015 & 0,64 & 0,79 & 0,66 & 0,73 & 0,80 & 0,79 \\
\hline 2016 & 0,72 & 0,82 & 0,70 & 0,73 & 0,81 & 0,83 \\
\hline 2017 & 0,80 & 0,87 & 0,69 & 0,73 & 0,81 & 0,81 \\
\hline 2018 & 0,80 & 0,86 & 0,68 & 0,70 & 0,80 & 0,78 \\
\hline 2019 & 0,86 & 0,28 & 0,58 & 0,50 & 0,66 & 0,45 \\
\hline & & & 0,67 & & \\
\hline
\end{tabular}

Źródło: obliczenia własne na podstawie: United Nations Conference on Trade and Development, https://unctadstat.unctad.org/wds/TableViewer/tableView.aspx, [dostęp 12.10.2019] 
W analizowanym okresie istotną, pozytywną cechą, charakterystyczną dla rozwoju eksportu Polski na rynki państw PW, był wyraźny wzrost dopasowania jego struktury do struktury popytu importowego państw- partnerów handlowych. W 2019 roku - co warto podkreślić - stopień odpowiedniego dopasowania był najwyższy w obrotach handlowych z Armenią, Mołdawią i Białorusią. Spowodowało to m.in. efekt relatywnie bardziej intensywnego rozwoju wewnątrzgałęziowego podziału pracy i relatywnie bardziej intensywnej wymiany czynników wytwórczych z tymi właśnie krajami.

\section{Współpraca inwestycyjna Polski z państwami PW}

Ze względu na relatywnie niską intensywność wymiany handlowej między Polską a państwami PW większego znaczenia nie mały dotychczas pośrednie przepływy czynników wytwórczych (tj. poprzez handel) i różne tego typu potencjalne skutki, zwłaszcza względne i absolutne wyrównanie się cen (dane tabel 6-9).

Współpraca inwestycyjna między Polską i Armenią ma zasięg bardzo ograniczony. Polskie firmy działają w Armenii bądź planują podjąć tam działalność m.in. w sektorze sprzętu ochronnego, OZE i IT. W Polsce praktycznie brak jest armeńskich inwestycji bezpośrednich. Indywidualną działalność w Polsce prowadzi ponad 570 (liczba zmienna) biznesmenów posiadających obywatelstwo Armenii (Armenia, 2019). Zanotowana przez Ambasadę Polską w Erewaniu polska inwestycja w Armenii, o wartości ok. 889 tys. USD, miała miejsce w 2014 roku. Dotyczyła kategorii „produkcja odzieży” (Armenia. Informacja o kraju, 2020).

W ostatnich latach można zaobserwować wzrost zainteresowania polskich firm rynkiem ormiańskim. W 2011 roku Polska Wytwórnia Papierów Wartościowych wygrała przetarg na tachografy cyfrowe oraz druk nowoczesnych dokumentów. Od 2012 roku w Armenii działa zbudowany przez PWPW system wydawania paszportów i kart ID obejmujący obsługę ponad 60 biur regionalnych na terenie całego kraju. W 2013 roku powstała spółka Lubawa Armenia, której udziałowcami są Lubawa S.A. i Charentsavan Machine Tool Factory (należąca do Ministerstwa Obrony Armenii). Spółka ma produkować siatki maskujące, makiety uzbrojenia i namioty dla wojska i służb mundurowych. Wciąż jednak przeszkodą do wchodzenia polskich 


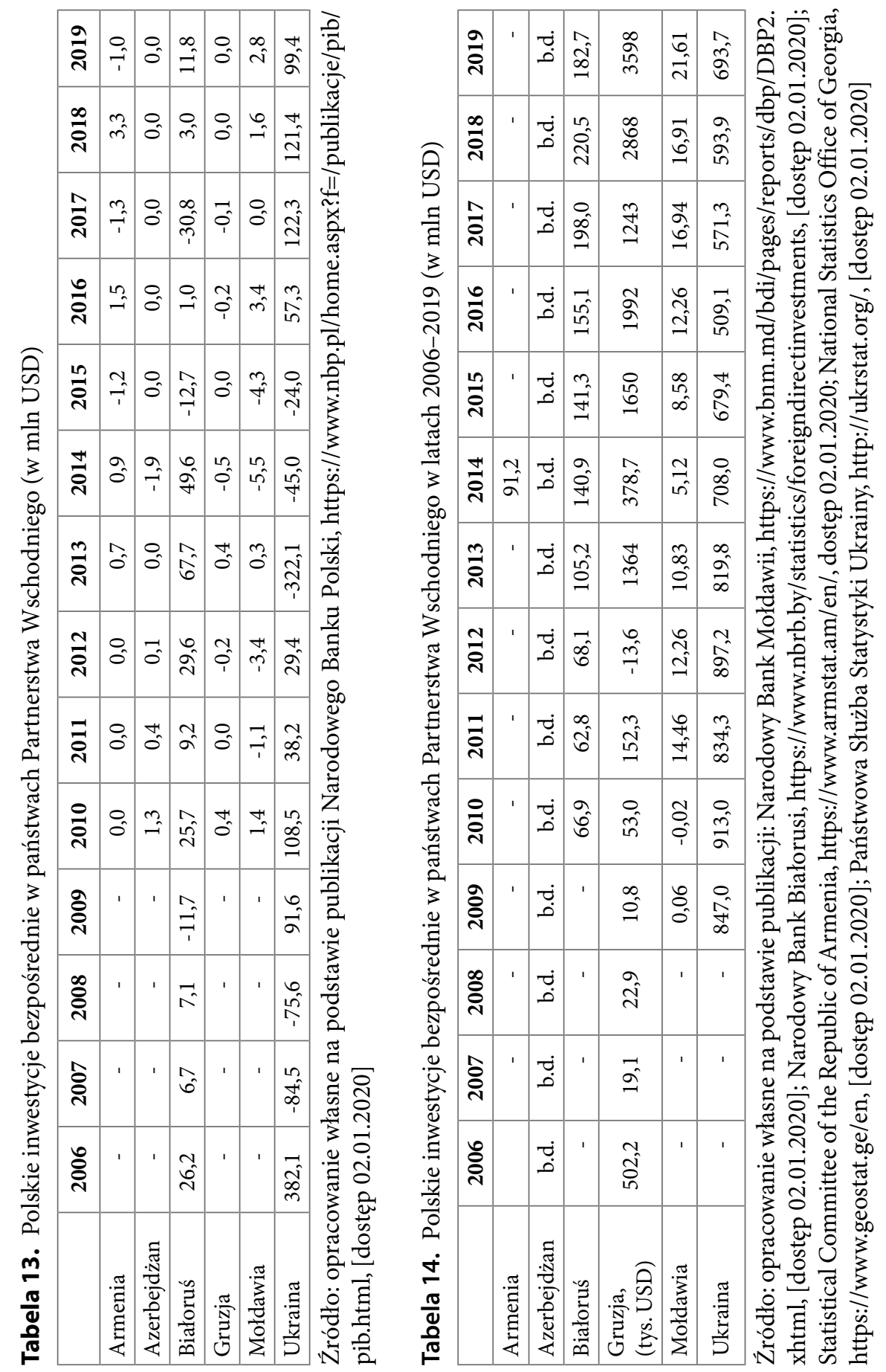


przedsiębiorstw na rynek armeński jest jego odizolowanie i płytkość oraz struktury oligarchiczne, które bronią swoich pozycji monopolistycznych (Informacje praktyczne dla polskiego eksportera - Armenia, 2020).

Zaangażowanie kapitałowe przedsiębiorców z Polski i z Azerbejdżanu jest nieznaczne.

W Azerbejdżanie zarejestrowano 17 spółek z polskim kapitałem, w tym w sektorze usług i doradztwa, materiałów budowlanych, rolno-spożywczym, farmacji, wyposażenia gastronomii, urządzeń energetycznych i usług bankowych. W Polsce także brak jest znaczących inwestorów z Azerbejdżanu. Jednoosobową działalność gospodarczą prowadzi ok. 40 przedsiębiorców z obywatelstwem Azerbejdżanu, głównie w sektorze handlu (art. rolnicze, przemysł lekki, meble, wyroby metalowe), usług (elektryczne, naprawy i konserwacja) i in. Przedsiębiorcy z Azerbejdżanu wykazują zainteresowanie wchodzeniem na polski rynek głównie w sektorze rolniczym (Azerbejdżan, 2019).

Głównym obszarem zainteresowania polskich inwestorów na gruzińskim rynku były sektory: finansowy, energetyczny, transportowy i budowlany. Należała do nich także branża farmaceutyczna, w której w 2011 roku na terenie Gruzji działała polska firma PPF HASCO-LEK S.A. Polskie firmy działające w branży budowlanej wykonywały w Gruzji remonty szpitali, ośrodków rehabilitacyjnych i obiektów turystycznych (Gomółka, Borucińska-Dereszkiewicz, 2015, s. 228-229). W drugiej połowie 2012 roku polskie przedsiębiorstwa rozpoczęły przygotowania do budowy huty w Kutaisi (Polskie firmy..., 2016). W 2013 roku w rynek gruziński zainwestowała firma Asseco Poland. Nabyła większościowe udziały w gruzińskiej spółce IT Onyx Consulting (Coraz więcej polskich ..., 2016). Aktualnie, według prezesa Polsko-Gruzińskiej Izby Przemysłowej:

Polskie przedsiębiorstwa w Gruzji są zainteresowane głównie branżą przemysłową, dużymi projektami infrastrukturalnymi, takimi jak budowa dróg czy portów oraz rozbudową infrastruktury hotelowej kubaturowej. Aktualnie w Gruzji powstaje port głębinowy w Anaklii, modernizowany i rozbudowywany będzie też port w Poti. Gruzja jest hubem komunikacyjnym łączącym Wschód z Zachodem, prowadzi przez nią jedyna droga do Chin z pominięciem Rosji, więc geostrategicznie Gruzja pełni ważną funkcję jako szlak komunikacyjny (Polscy przedsiębiorcy coraz..., 2019). 
Polska należy do widocznych inwestorów zagranicznych na Białorusi, mimo iż wciąż są to inwestycje niewielkie w wartościach bezwzględnych, a ich poziom, w porównaniu z innymi krajami-źródłami inwestycji na Białorusi, pozostaje niski. Według danych Narodowego Banku Republiki Białorusi (NBRB) na styczeń w 2020 roku Polska zainwestowała 182,7 mln USD. Udział polskich inwestycji w ogólnej wielkości bezpośrednich inwestycji zagranicznych na Białorusi w dniu 1.I.2020 roku wynosił jedynie 1,3\%. Według danych Narodowej Agencji ds. Inwestycji i Prywatyzacji na początku 2019 roku na Białorusi zarejestrowanych było 345 podmiotów z kapitałem pochodzącym z Polski. Według tejże instytucji, w okresie styczeń-wrzesień 2019 roku z Polski na Białoruś napłynęło 282,9 mln USD inwestycji brutto, w tym 270,5 mln USD - bezpośrednich inwestycji zagranicznych (BIZ), z tego 25,3 mln USD - to BIZ netto. Głównym kierunkiem inwestycji polskich firm na Białorusi stały się w ostatnich latach: miejscowy przemysł drzewno-meblarski, przemysł rolno-spożywczy, sektor budownictwa i materiałów budowlanych, logistyka i handel detaliczny (Białoruś. Informator ekonomiczny, 2020).

Zaangażowanie polskiego kapitału w gospodarkę Mołdawii jest niewielkie i rozdrobnione, a w wielu przypadkach sprowadza się tylko do rejestrowania swojej obecności na rynku. Jak można się dowiedzieć ze strony Serwis Rzeczypospolitej Polskiej (Mołdawia. Informator Ekonomiczny, 2020), wg stanu na 31 grudnia 2019 roku wśród zarejestrowanych w Republice Mołdawii przedsiębiorstw z udziałem kapitału zagranicznego ze wszystkich krajów świata, mamy 103 firmy z pełnym lub częściowym udziałem kapitału polskiego (można $\mathrm{z}$ dużym prawdopodobieństwem ocenić, iż ok. 1/3 firm z kapitałem polskim praktycznie nie prowadzi działalności: nie wypełniły one obowiązku formalnego uregulowania swojego statusu, lecz nadal figurują). W 2019 roku na terenie Republiki Mołdawii została zarejestrowana jedna firma z kapitałem polskim. Od dekady największym polskim inwestorem jest Krajowa Spółka Cukrowa SA. Drugą znaczącą polską inwestycją bezpośrednią jest Plastics Moldova - przedsiębiorstwo handlujące wyrobami z tworzyw sztucznych, wykorzystywanymi głównie w reklamie i budownictwie. Ponadto polskie inwestycje w Republice Mołdawii dotyczą przeważnie budownictwa, przemysłu przetwórczego i handlu. Zainteresowanie inwestowaniem zaczęło także dotyczyć usług budowlanych, transportowych oraz pośrednictwa pracy. W latach 2015-2019 szereg polskich firm rozeznawało również możliwości 
inwestowania w branży ceramiki budowlanej, meblarskiej, utylizacji odpadów oraz budowy małych elektrociepłowni.

Według stanu na 31 grudnia 2019 roku polskie inwestycje na Ukrainie miały wartość 210,3 mln USD (Narodowy Bank Ukrainy, 2020). Polski kapitał stanowi 3,6\% w łącznej strukturze bezpośrednich inwestycji zagranicznych na Ukrainie. Pomimo nominalnie niewielkiej skali polskie inwestycje na Ukrainie są zauważalne, zwłaszcza że dominująca część inwestycji to powracający kapitał ukraiński. Polski kapitał na Ukrainie koncentruje się w sektorze bankowo-finansowym (ok. 26\%) oraz w przemyśle - przede wszystkim przetwórczym (ok. 47,5\%). Znaczna część polskich inwestycji przypada również na handel i usługi (10,7\%) (Państwowa Służba Statystyki Ukrainy, 2019).

\section{Podsumowanie}

Rozwój i aktualny stan powiązań gospodarczych Polski z państwami Partnerstwa Wschodniego można oceniać na różne sposoby. Jak się wydaje, najbardziej uzasadnione jest dokonywanie odpowiednich ocen przy wykorzystaniu odpowiedniego dorobku teoretycznego, na który składają się m.in.: teoria lokalizacji działalności gospodarczej w świecie (location theory), a zwłaszcza tzw. nowej geografii ekonomicznej (new economic geography), teorie wymiany międzynarodowej, tj. teorie handlu międzynarodowego oraz teorie międzynarodowych przepływów czynników wytwórczych (theory of international economics) (Misala, 2008, s. 30).

I tak, biorąc pod uwagę dorobek teorii lokalizacji działalności gospodarczej, można zauważyć, że dotychczasowy i aktualny stan powiązań gospodarczych Polski z państwami Partnerstwa Wschodniego ilustrują symptomatyczne fakty:

- między Polską a państwami PW występują różnice nie tylko w potencjale gospodarczym, ale państwa PW w porównaniu z Polską maja relatywnie niski i zarazem zróżnicowany stopień skuteczności jego wykorzystania;

- Polska i państwa PW mają różny stopień uczestnictwa w międzynarodowym podziale pracy; 
- Polska i państwa PW różnie wykorzystują możliwości, jakie stwarza dla rozwoju kraju wymiana międzynarodowa;

- Polska i państwa PW mają zróżnicowany stopień zdolności koordynowania ekspansji handlowej z szeroko rozumianą ekspansją kapitałową i naukowo-technologiczną.

Z wyżej wymienionych powodów dotychczas i aktualnie największe znaczenie gospodarcze dla Polski ma Ukraina. Za nią kolejno plasują się: Białoruś, Mołdawia, Gruzja, Azerbejdżan i Armenia. Jednak w analizowanym okresie Polska wciąż nie wykorzystuje w pełni bliskości geograficznej, chłonności rynków wewnętrznych partnerów i możliwości osiągania tzw. korzyści skali, czy też istnienie komplementarności międzygałęziowej i wewnątrzgałęziowej oraz możliwości ich pogłębienia, zwłaszcza w odniesieniu do komplementarności typu wewnątrzgałęziowego.

Poza tym, dodatkowo na przebieg relacji gospodarczych negatywnie oddziałują czynniki pozaekonomiczne (np. uprzedzenia czy niechęć do współpracy), które partnerom trudno przezwyciężyć. W tej sytuacji zasadne wydaje się wzmocnienie pozytywnego oddziaływania różnorodnych czynników o charakterze ekonomicznym i nie tylko np. kontaktów polityków, ludzi nauki, kultury, młodzieży studiującej itp.W kolejnych latach na intensyfikację powiązań gospodarczych Polski z państwami PW może mieć wpływ lepsze wykorzystanie potencjału gospodarczego w państwach PW oraz wzmocnienie międzynarodowej konkurencyjności polskiej gospodarki.

\section{DR KAROLINA KOTULEWICZ-WISIŃSKA}

Katedra Studiów Politycznych

Instytut Politologii, Filozofii i Socjologii

Kolegium Gospodarki i Administracji Publicznej

Uniwersytet Ekonomiczny w Krakowie

ul. Rakowicka 27, 31-510 Kraków

kotulewk@uek.krakow.pl

\section{Bibliografia}

Ambasada Republiki Azerbejdżanu w Rzeczypospolitej Polskiej (2021). Pobrane z: https:// warsaw.mfa.gov.az/pl/content/3/stosunki-dwustronne. 
Armenia (2020). Pobrane z: https://www.gov.pl/web/armenia/armenia.

Armenia. Informator ekonomiczny. (2019). Pobrane z: https://www.gov.pl/web/armenia/ informator-ekonomiczny.

Armenia. Informacja o kraju. (2019). Pobrane z: https://erywan.msz.gov.pl/pl/ wspolpraca_dwustronna/informator_ekonomiczny/informacje_o_kraju.

Azerbejdzan. Informator ekonomiczny. (2020). Pobrane z: https://www.gov.pl/web/ azerbejdzan/informator-ekonomiczny.

Азербайждан: ресурсная модель экономического роста. (2018). Бюллетень о текущих тенденииях мировой экономики Аналитический Центр при правительстве Российской Федерации, 39, декабрь.

Białoruś. (2020). Pobrane z: https://www.gov.pl/web/bialorus/relacje-dwustronne.

Białoruś. Informator ekonomiczny. (2019). Pobrane z: https://www.gov.pl/web/bialorus/ informator-ekonomiczny.

Borucińska-Dereszkiewicz, I. (2017), Stosunki handlowej i inwestycyjne Polski z Armenią po 2004 roku. Nowa Polityka Wschodnia, 4(15), 148-149.

Coraz więcej polskich firm chce inwestować w Gruzji. (2016). Pobrane z: http://inwestycje. pl/inwestycje_zagraniczne/Coraz-wiecej-polskich-firm-chce-inwestowac-w-Gruzji;173294;0.html.

Czachor, R. (2013). Stosunki polsko-białoruskie. Pobrane z: https://depot.ceon.pl/bitstream/handle/123456789/15167/Polityka_12_Czachor.pdf?sequence $=1$.

Czechowska, L. (2017). Stosunki dwustronne RP w latach 1990-2002 na podstawie analizy corocznych informacji rzadu o polityce zagranicznej państwa. Toruń: Fundacja Copernicus na rzecz Rozwoju Badań Naukowych.

Экономика Армении во второй половине 2018 года. (2018). Pobrane z: https://www. kavkaz-uzel.eu/blogs/83781/posts/35830.

Embassy of Georgia to the Republic of Poland. (2020). Pobrane z: http://www.poland. mfa.gov.ge/.

Gomółka, K., Borucińska-Dereszkiewicz, I. (2015), Stosunki Polski z Armenią, Azerbejdżanem i Gruzja na przełomie XX i XXI wieku. Toruń: Wydawnictwo Adam Marszałek.

Gruzja. Relacje dwustronne. (2019). Pobrane z: https://www.gov.pl/web/gruzja/ relacje-dwustronne.

Geremek, B. (1998). Informacja Ministra Spraw Zagranicznych o podstawowych kierunkach polityki zagranicznej Polski przedstawiona na 13. posiedzeniu Sejmu RP III Kadencji, 5.03.1998. Pobrane z: http://orka2.sejm.gov.pl/Debata3.nsf/03774ccd33634cb4c1257233006a570a/73a6e30274030d5ac1257491003e25d1?OpenDocument.

Informacje praktyczne dla polskiego eksportera - Armenia. (2020). Pobrane z: https:// www.trade.gov.pl/pl/analizy-rynkowe/azja/armenia/227012,informacje-praktyczne-dla-polskiego-eksportera-armenia.html.

Kotulewicz, K. (2011). Współpraca gospodarcza i polityczna Polski z Republik a Mołdową w ostatnim 20-leciu. W: J. Dzwończyk, J. Kornaś (red.). Transformacja polska - oczekiwania i rzeczywistość. Kraków: UEK i Fundacja UEK. 
Kotulewicz, K. (2014). Przebieg współpracy Polski i Republiki Mołdawii w ramach Programu „Partnerstwo Wschodnie”. W: J. Kornaś, Ł. Danel (red.). 25-lat polskiej transformacji systemowej. Dokonania i wyzwania. Kraków: Wydawnictwo AGH.

Mekvabishvili, E., Beridze, Т. (2018). Тернистьй путь экономических реформ в посткуммунистической Грузии. Ретроспектива и перспектива. Pobrane z: https://www.researchgate.net/publication/324748295.

Misala, J. (red.). (2008). Współpraca Gospodarcza Polski ze wschodnimi krajami sąsiedzkimi oraz Estonią, Łotwa i Mołdową. Dotychczasowy Rozwój i Perspektywy. Radom: Politechnika Radomska.

Mołdawia. Informator Ekonomiczny. (2020). Pobrane z: https://www.gov.pl/web/ republikamoldawii/informator-ekonomiczny.

Narodowy Bank Białorusi (2020). Pobrane z: https://www.nbrb.by/statistics/foreign directinvestments.

Narodowy Bank Polski (2020). Pobrane z: https://www.nbp.pl/home.aspx?f=/publikacje/ pib/pib.html.

Narodowy Bank Ukrainy (2020). Pobrane z: https://bank.gov.ua/ua/statistic/ sector- external/data-sector-external $\# 5$.

National Statistics Office of Georgia (2020). Pobrane z: https://www.geostat.ge/en.

Państwowa Służba Statystyki Ukrainy (2020). Pobrane z: http://ukrstat.org/.

Polskie firmy chca inwestować w Gruzji. (2016). Pobrane z: https://mambiznes.pl/ wlasny-biznes/wiadomosci/polskie-firmy-chca-inwestowac-w-gruzji-11072.

Polscy przedsiębiorcy coraz uważniej przyglądają się Gruzji. Przyciagaja ich tam chłonny rynek i liczne inwestycje w infrastrukturę. (2019). Pobrane z: https://biznes.newseria. $\mathrm{pl} /$ news/polscy-przedsiebiorcy,p358723216.

Raport o stanie sektora małych i średnich przedsiębiorstw 2020. (2020). Warszawa: Polska Agencja Rozwoju Przedsiębiorczości.

Relacje dwustronne Polska - Azerbejdżan. (2019). Pobrane z: https://www.gov.pl/web/ azerbejdzan/azerbejdzan.

Republika Gruzji (2020). Pobrane z: https://sip.lex.pl/akty-prawne/dzu-dziennik-ustaw/ gruzja-polska-traktat-o-przyjazni-i-wspolpracy-tbilisi-1993-04-20-16861544.

Statistics on small and medium-sized enterprises in EU and the Eastern Partnership countries. (2019). The European Commission. Pobrane z: https://ec.europa.eu/ i www. eu4business.eu.

Trade Statistics for International Business Development (2020). Pobrane z: https://www. trademap.org/.

Traktat sporządzony w Tbilisi dnia 20 kwietnia 1993 r. o przyjaźni i współpracy między Rzecząpospolitą Polska a Republika Gruzji. (1999). Pobrane z: https://sip.lex.pl/ akty-prawne/dzu-dziennik-ustaw/gruzja-polska-traktat-o-przyjazni-i-wspolpracy -tbilisi-1993-04-20-16861544.

Statistical Committee of the Republic of Armenia. (2020). Pobrane z: https://www. armstat.am/en/.

Ukraina. (2020). Pobrane z: https://www.gov.pl/web/ukraina/relacje-dwustronne.

United Nations Conference on Trade and Development. (2020). Pobrane z: https://unctadstat.unctad.org/.

World Bank. (2020). Pobrane z: https://databank.worldbank.org/. 